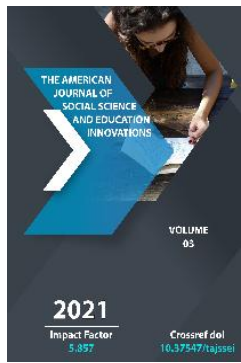

\title{
The Role Of Module Teaching System In Increasing Lesson Efficiency
}

Nishonova Dilnavoz Jonibekovna

Department Of Teaching Languages, Fergana Polytechnic Institute, Fergana, Uzbekistan

Journal Website:

http://theamericanjour

nals.com/index.php/taj

ssei

Copyright: Original content from this work may be used under the terms of the creative commons attributes 4.0 licence.

\section{ABSTRACT}

This article analyses the work being done and achievements in the field of modular training, which is one of the most pressing issues in the education system of the country. The requirements and rules required for modular training, the purpose and essence of modular training technology are explained.

\section{KEYWORDS}

Teaching technology, teaching elements, methodical handouts, individual assignments, educational scientific literature, modular teaching technologies.

\section{INTRODUCTION}

The idea of modular learning technology originated in the United States in the 1960s,

and was first discussed internationally at the 1972 UNESCO World Conference in Tokyo, and 
was described in the 1982 Paris Declaration as follows: A module is a separate training package (set) designed to provide one or more skills in individual or group training through exercises, a careful acquaintance at a specific pace, and sequential learning [1-5].

So far, significant work has been done in the country on the practical application and introduction of modular learning technology in the educational process.

In particular, the research of N.H. Avliyokulov and K.T. Olimov [3-4] on the design stages of pedagogical technology and the development of principles of modular teaching, the research on the general principles of modern pedagogical technologies.

\section{MATERIALS AND METHODS}

The main objectives of the transition to modular learning technology are:

- Ensuring continuity of education (integration between disciplines);

- Individualization of the learner;

- Creation of conditions for increasing the effectiveness of independent learning in exchange for the creation of a bank of materials necessary for the learning process;

- Accelerate learning;

- Improving the quality of theoretical knowledge, as well as professional skills.

- As for the essence of the organization of the educational process based on modular learning technology, the learner achieves the specific goals of the activity in order to gain knowledge in working with each module of the subject or independently, in whole or in part with the advice of the teacher.

- The main requirements of modular training technology are:

- Setting a goal for the content of each module to master all the learning elements of the material;

- The module is aimed at achieving one or more didactic goals;

- The content of the modules should be focused on independent thinking, logical thinking and practical activities;

- In order to develop professional and creative thinking, it is necessary to achieve a problematic presentation of the content of the training material of the module.

In modular training, the knowledge, skills and abilities of students must be strictly evaluated in the rating system of control.

The training materials prepared for each module include a modular program covering the entire study period, theoretical materials (lectures), teaching materials, individual assignments, a list of educational and scientific literature, assignments for independent work and control assignments.

For the development and implementation of modular learning technology, it is advisable to do the following:

- Development of a modular curriculum of science-based on state educational standards; 
- Development of curriculum for each subject on the basis of standard modular technology:

- Development of a working syllabus of the subject on the basis of a modular curriculum:

- Creation of a system of methodical instructions and guidelines for the database of the educational element listed in the syllabus, the performance of accounting and graphic work, assignments for independent and individual work;

- Development of the procedure for conducting intermediate and current controls to monitor the level of mastery of learning elements;

- Create test questions by the module to perform final control on each module.

The effectiveness of the transition of each subject to a system of modular teaching technology can be assessed depending on the following factors:

- The level of provision of the department with modern material and technical means on the subject;

- Qualification level of teaching staff on the subject;

- level of creation of educationalmethodical materials, tools and electronic information database on the subject in accordance with the requirements of modular technology;

- level of comprehensibility and mastery of didactic materials;
- Improving the learning elements in the modules based on the analysis of the results obtained;

- A set of handouts and illustrated materials for each learning element is given to the student before the lesson.

In the process of creating modules in science, students gain certain practical skills through the theoretical part of the learning elements (lectures) and the logical connection of practical lessons and laboratory work associated with them [5-7].

In the preparation of each element of the module, its structure in small blocks, presentation of teaching materials in block diagrams and visualization, problem-based and instructive lectures in the form of educational technology and technological maps, which provide generalized information on key issues of science, increase the effectiveness of the subject.

Depending on the nature and essence of the science, the modules can be structured as follows: [7-9]

- Historical - a brief description of the history of the problem, theorem, problem, concept;

- Problematic - problem formulation;

- Systematic - systematic presentation of the module content;

- Activation - highlighting the basic phrases and methods of action needed to master the new learning material; 
- Theoretical - the main educational material, in which - didactic goals, problem expression, substantiation of hypotheses, ways to solve the problem;

- Experimental - describes the experimental material (study experience, work, etc.)

- To reach;

- Generalization - generalization of the image of the problem solution and the content of the module;

- Application - the development of new methods of action and a system of issues for the practical application of the studied material;

- Errors - to reveal the same types of errors observed by the student in mastering the content of the module, to identify their causes and show ways to correct them;

- Connection - to show that the passed module is connected with other modules, including related disciplines;

- Deepening - providing complex learning materials for gifted students;

- Test-test - control and assessment of the level of mastery of the module content by students using tests.

\section{CONCLUSION}

Thus, the development and implementation of modular teaching technology in science:

- Acceleration of the educational process on the basis of mutual integration of disciplines;
- Increase the level of interdependence within the module and with other modules in the study of topics;

- A systematic approach to defining and building a component of science;

- Effective control of students' knowledge on the basis of modules;

- Implementation of additional classes, consultative activities in a short period of time in exchange for determining the level of mastering the subject by students;

- Provides development of creative approach skills in mastering the subject by students.

\section{REFERENCES}

1. National training program. Book: Harmoniously developed generation is the foundation of Uzbekistan's development. Tashkent: Sharq, 1997. 32-61 p.

2. Avliyoqulov N.H. (2001). Practical bases of a modular system of teaching and pedagogical technology. Methodical manual. Buxoro. P. 49

3. Askarov I. B. (2013). Application of modular teaching technology in teaching the subject "Maintenance and repair of cars and engines" in professional colleges. A dissertation written for a master's degree. Tashkent

4. Nishonova, D. Zh. (2019). Ispol'zovanie interaktivnyh metodov na urokah nemeckogo jazyka [Use of interactive 
methods on the lesson of the German language]. Voprosy nauki i obrazovanija, (4 (49)). (in Russian).

5. Jonibekovna, N. D., Gulomovna, B. G., Salimovna, T. O., \& Karimovna, M. O. (2020). Some opinions about parameters of mnemonics. Universal Journal of Educational Research, 8(1), 238-242.

6. Nishonova, D. J., Muminova, O. K., \& Ismoilova, F. A. (2019). Metod proektnyh rabot $\mathrm{v}$ obrazovatel'nom processe [Method proektnyx rabot in obrazovatelnom protsesse]. Vestnik nauki i obrazovanija, (19-2 (73)). (in Russian).

7. Nishonova, D. J. (2018). Sredstva, modeli i prijomy pri obuchenii inostrannomu jazyku [Means, models and techniques for teaching a foreign language]. Dostizhenija nauki i obrazovanija, 1 (8 (30)). (in Russian).

8. Nishonova, D. J. (2018). Portfolio kak odin iz al'ternativnyh sposobov ocenivanija znanij uchashhihsja v processe obuchenija inostrannym jazykam [Portfolio as one of the alternative ways of assessing students' knowledge in the process of teaching foreign languages]. In Nauka I Obrazovanie: Sohranjaja Proshloe, Sozdajom Budushhee (pp. 235-237). (in Russian).

9. Nishonova, D. J. (2017). Teorija i metodika obuchenija inostrannomu jazyku v vuze [Theory and methodology of teaching a foreign language at the university]. Nauchnye issledovanija, 1 (6 (17)). (in Russian). 